\begin{tabular}{|l|l|}
\hline D0l:10.17951/we.2020.6.2.97-113 & Wschód Europy • Восток Европы • East of Europe vol 6, 2 / 2020 \\
\hline
\end{tabular}

Oleh Kotlyar

Vasyl Stefanyk Precarpathian National University

ORCID ID: https://orcid.org/0000-0003-0740-4238

\title{
Features of Swedish and Norwegian foreign policy towards Russia: Main problems and challenges
}

\section{Introduction}

As is widely known, the challenges of recent years have tested the international security system, integrity of the European Union, and consensus of European partners on the common policy relating to new complicated reality of global political situation. One of the major destabilizer of international security system and European integrity is Russian Federation (hereinafter - the RF). The violation of international law by Russia, concerning sovereignty and integrity of independent states, that particularly resulted in illegal annexation of Crimea and conflict in the Eastern Ukraine, is a significant reason for identification of the RF as an aggressor. We can state the fact of deterioration in relations between the West and Russia that therefore influences on foreign-policy activities of Sweden and Norway.

Taking into account the geographical position of the RF, Scandinavian states have to pay a considerable attention to the Russian vector of foreign policy. In this regard, Norway has to pay more attention to this vector, unlike Sweden, as Norwegians have $195.7 \mathrm{~km}$ of common border with Russians, that entails wider range of cooperation and higher level of the development of bilateral relations. Besides, the common border, joint activity of Norway and Russia in the Arctic region, as well as difference in implementation of security and defense policy (non-aligned status of Sweden and North Atlantic Treaty Organization membership of Norway) are those factors which determine nature of relationship of Sweden and Norway with RF.

Accordingly, the aim of this article is to define the features of Swedish and Norwegian foreign policy towards Russia, considering the geopolitical circumstances of its development and implementation within the period of 1990-s-2019.

Key points of the article are based on the official documents of the foreign policy departments of Sweden and Norway.In particular, the documents prepared by the Ministry of Foreign Affairs of Sweden on the strategy for development of relations with 
Russian Federation, and the Norway's High North policy strategy, which includes the issue on cooperation with Russia in the region. It was analyzed the several annual statements of the ministers for foreign affairs of Sweden and Norway (for the period of 2007-2015), where both states, among other things, declared their stances on relations with Russia. A significant part of bibliography includes the articles from electronic periodical, where the authors provide the information on relations between Scandinavian countries and Russia in the context of Ukrainian-Russian conflict and increasing of Russian military activity in the North and Baltic region. Among the sources of scientific-research character it should be noted the work of Eva Frisell ${ }^{1}$ (Senior Analyst of the Swedish Defense Research Agency), whose main area of research is European security and, in particular, Russian influence on the security of Sweden. The scientific work of Ingmar Oldberg (Deputy Director of the Swedish Defense Research Agency) is also very important in terms of the issues researched in the article. In particular, the useful information on the issue is provided in the article of the researcher about the Northern European vector of Russia's foreign policy².

Methodological basis of the article consists of explication methods of content and event analysis. For instance, the content analysis was used in the process of research of the official foreign policy documents on relations with RF and security aspects of the Scandinavian countries' foreign policy. The using of event analysis was conducted during research of the influence of Russian aggression in Georgia and Ukraine, as well as increasing of Russian military activity in the North and Baltic region, on the foreign policy of Sweden and Norway towards Russia. In addition to the above-mentioned explication methods, the author has also implemented a comparative method with the purpose of comparing of Norway's and Sweden's approaches to relations with RF in the context of Norway's NATO membership and Sweden's non-alignment policy in the current state of international security system. Methodological basis of the article also includes historical and chronological methods of research by which the author describes the sequence of Russian vector of foreign policy conducted by Scandinavian countries, as well as the features of this vector at each stage.

\section{Hopes for new quality of relations with Russia}

With the collapse of the Union of Soviet Socialist Republics and emergence of the RF on the international stage, Scandinavian countries were looking forward to fundamental change of situation regarding relations with Russian neighbor. The main expectations at the beginning were put on detensioning between West and Russia, due to the end of bloc confrontation. This is particularly true for Norway as a member of NATO, since with the end of this confrontation the country could reduce its military alert and focus on other activities. New international realities allowed non-aligned Sweden to

\footnotetext{
E. Frissel, I. Oldberg, “Cool Neighbors”: Sweden’s EU Presidency and Russia, IFRI, 2009, № 42, p. 10.

2 I. Oldberg, Russia's "northern" foreign policy, Research Associate Swedish Institute of International Affairs, Stockholm, 2011, p. 3.
} 
reduce its military expenditures as well. Thus, the 90's became a period of disarmament and demilitarization of Scandinavian-Russian relations.

In addition, the period of the 90's-early 2000's was a time of development of treaty and legal framework for political and economic cooperation, that became a basis of Russian vector of Swedish and Norwegian foreign policy. Both states declared supporting the transition of the RF to democratic governance and sustainable market economy as their main task on this vector. Such support would have contributed to integration of the RF into European and world institutions, as well as to investments from Sweden and Norway to Russia.

The above tasks were indicated in the official documents of Scandinavian countries. In particular, Sweden started to create national strategy for development of relations with Russia in the early 2000's. The strategy is based on a project that includes proposals of the Swedish International Development Cooperation Agency (SIDA). These proposals are complemented by the approaches of the Ministry for Foreign Affairs of Sweden and other ministries who are involved in cooperation with $\mathrm{RF}^{3}$. The contents of early developed strategies are quite similar. The main attention is paid to necessity of further deepening of contacts, support for reforms, maintaining of regional stability, as well as support for integration of the RF into European institutions and World Trade Organization.

In particular, the general provisions of the strategies for 2002-2004 and 2005-2008 state that cooperation with Russia should be focused on further reforming the country that would contribute to stable development, as well as poverty reduction. It is indicated in the documents, that democratic development and growth of economic welfare of Russia, its closer cooperation with European institutions and strengthening of its international relations contribute to the increase of regional stability.

Common for both strategies is the view, that key directions of Swedish-Russian cooperation should remain development of democracy, economic transformations, social protection of the population, environmental issues, collective security, and cooperation in science and technology 4 .

Norway, for its part, also emphasized on humanitarian component in the official documents. For example, it is emphasized, among other things, on such issues as democracy, human rights, rule of law in "High North Strategy" foreign policy document. It is explained in this strategy the importance of development of above components in the RF for Norway. Moreover, the document notes, that Norway will be as outspoken as possible with Russia in the dialogue regarding rule of law and state of democracy in this country.

Norway provided financial support for development of democracy in the RF. For example, in 2007 under the framework of the Project Cooperation with Russia, Norway

\footnotetext{
3 "Country strategy for development cooperation with Russia 2002-2004", Ministry for Foreign Affairs, Department for Central and Eastern Europe, Stockholm, 2002, p. 1.

4 "Country strategy for development cooperation with Russia 2005-2008”, Ministry for Foreign Affairs, Department for Central and Eastern Europe, Stockholm, 2005, p. 2.
} 
allocated NOK 111.3 million, part of which was intended for development of democra$c y$, civil society in the north-west regions of the RF and people-to-people cooperation ${ }^{5}$.

It quickly became clear, that Norwegians had a point making such emphasis. The Russian leadership did not consider it necessary to move toward democratization and predictability. It became more noticeable when Vladimir Putin came to power. Thus, it influenced on attitude of Northern European countries towards Russia. For instance, Sweden in annual report on foreign policy activity which is usually announced in the Statement of Government Policy in the Parliamentary Debate on Foreign Affairs, has been emphasizing the country's desire to see Russia as a reliable and democratic partner from the middle of the 2000's. In particular, in such document of 2007 the following is stated: "Since the collapse of the Soviet system we have put great hopes in the democratic transformation of Russian society [...] In many respects these expectations have already been fulfilled. In terms of business activity and human contacts, we are witnessing a development the like of which has not been seen in a century [...] However, in important respects developments in the last few years have also involved steps backwards. The political climate and the media climate alike have become less free $e^{6 .}$.

Sweden recalled the negative impact of such cases as unsolved murders of journalist Anna Politkovskaya and defector Alexander Litvinenko in the mentioned earlier strategies for development of relations with Russia. Moreover, in comparison with the majority of EU members, Sweden demonstrated more stronger criticism of Russia's "counter-terrorism operation" in Chechnya and called for political solution of this conflict ${ }^{7}$. The differences between Stockholm and Moscow lay in their attitudes towards Baltic states. Thus, Sweden consistently supported these states in their integration into the EU and NATO. But Russia, on the contrary, always tried to interfere with this integration process of Baltic states ${ }^{8}$.

\section{Influence of Georgian case on Russian vector of foreign policy}

Temporary sharpening of position of Scandinavian countries towards Russia originated in 2008. The reason for that was the Russian aggression in Georgia. Sweden's position was especially critical. In particular, one of the main critic was the Minister for Foreign Affairs Carl Bildt. Swedish Minister for Foreign Affairs condemned the intervention of Russian troops in Georgia in August 2008 as an aggressive act incompatible with international law and fundamental principles of security and cooperation in Europe. C. Bildt visited Tbilisi during the conflict where expressed regret at Russian military intervention. Minister also called for immediate ceasefire and respect for the territorial

5 W. Gerhardsen, How Norway promotes democracy in North-West Russia, Oslo 2007, p. 39.

6 C. Bildt, Statement of Government Policy in the Parliamentary Debate on Foreign Affairs, Ministry for Foreign Affairs Sweden, Stockholm, 2007, p. 5.

7 Sweden helping Chechen 'bandits': Russia, https://www.thelocal.se/20100309/25432, access: 13 IX 2019.

8 I. Oldberg, Russia's "northern" foreign policy, Research Associate Swedish Institute of International Affairs, Stockholm, 2011, p. 3. 
integrity of Georgia 9 . He condemned the Russian practice of interference in the internal affairs of other state under the pretext of protecting Russian citizens or population possessing Russian passports. Moreover, the Minister compared the Russian actions to Serbian intervention in the states of former Yugoslavia and use of similar doctrine in the Central Europe by Hitler more than half a century ago ${ }^{10}$.

Along with other EU members, Sweden suspended bilateral military exchanges with Russia and decided not to decommission any more military garrisons as previously planned ${ }^{11}$. Criticism of Russian aggression towards Georgia was included in the official foreign policy documents of Sweden. For example, in the Statement of Government Policy in the Parliamentary Debate on Foreign Affairs for 2008 the following is stated: "Russia's aggression against Georgia and recognition of South Ossetia and Abkhazia as independent states represented not only an unacceptable violation of the territorial integrity of another state, but also a blow to the international law that is the very basis of peaceful and stable relations between states ${ }^{12}$."

As for Norway, this country also expressed condemnation but with less strict position regarding Russia's actions. For instance, the Minister for Foreign Affairs Jonas Gahr Store told about unacceptability of such actions and emphasized the seriousness of the situation which could have negative impact on Norwegian-Russian relations. He also noted that such cases might lead their cooperation with Russia in the High North to "demanding period"13. The same was stated in the Foreign Policy Report of the Ministry for Foreign Affairs to the Storting for 2008-2009. The Russia's actions were characterized as an act in breach of international law, as negative signal of Russia's readiness to use military force for such illegal activity. It was also mentioned that Norway would combine its close neighborly relations with RF and advantages of its NATO membership: "The Georgia crisis and its aftermath have revealed Russia's potential to use force and its vulnerability, as well as the uncertainty surrounding Russia's future, for example in the light of the financial crisis. These developments underscore the importance of combining a close neighborhood policy vis-à-vis Russia with a firm basis in Euro-Atlantic cooperation ${ }^{14}$."

But, sharpening of position of Scandinavian countries towards Russia regarding aggression in Georgia and general criticism regarding failure to respect human rights or reluctance to implement democratic development have not become serious obstacle for

9 C. Bildt, Russia's justification of its offensive deeply ominous, Ministry for Foreign Affairs Sweden, 2008.

10 Sweden invokes Hitler in condemning Russian assault, https://www.thelocal.se/20080809/13596, access: 13 IX 2019.

11 E. Frissel, I. Oldberg, “Cool Neighbors”: Sweden’s EU Presidency and Russia, IFRI, 2009, № 42, p. 10.

12 C. Bildt, Statement of Government Policy in the Parliamentary Debate on Foreign Affairs, Ministry for Foreign Affairs Sweden, Stockholm, 2009, p. 4.

13 T. Ekfeldt, High North - low tension?, Lund 2017, p. 14.

14 Interests, Responsibilities and Opportunities The main features of Norwegian foreign policy, Report No.15 (2008-2009) to the Storting, p. 11 
solving the further practical economic issues of cooperation. For example, strict criticism of Russia's actions in Georgia by C. Bildt, concerns that political development of Russia becomes more and more authoritarian ${ }^{15}$, and frequent statements of breach of international law caused by the RF contrasted with Sweden's consent to construct "Nord Stream" gas pipeline through its Exclusive Economic Zone ${ }^{16}$. This permit given by Sweden became the reason to talk about improving of bilateral relations between Scandinavian country and the RF after short-time aggravation in the background of C. Bildt's statements.

As for Norway, there were more options that softened negative impact of undemocratic nature of Russia and its aggression towards Georgia on the status of bilateral relations and features of Russian vector of Norway's foreign policy. These options are related to necessity of cooperation in the High North, as well as due to common border between states. For instance, one of the most important issue on the agenda back then was delimitation of maritime borders in the Barents region, which according to the relevant treaty signed in September 2010, was resolved ${ }^{17}$. "Barents issue" was important for Norway and Russia both in terms of regulation of territorial disputes, and resource potential of this region. Signing of the treaty above-mentioned therefore led to deepening of cooperation in the region with the purpose of joint resources development. Thus, the problems of democracy and respect for international law by Russia regarding cases which do not directly relate to Norway or nearby regions were often put on the background with the purpose to deal with range of more practical and objectively important tasks. In this way the Northern European country continued to implement "dual policy" towards Russia that combined NATO membership, periodic criticism on Russia's undemocratic policy on the one hand, and active cooperation in the High North on the other hand. The similar strategy had been successfully worked out during the Cold War and became the instrument of Norway's foreign policy particularly in relations with $\mathrm{RF}^{18}$.

In fact, Russian aggression in Georgia had not significant impact on Russian vector of foreign policy of both Scandinavian countries. It only caused temporary official criticism and statements that such activity negatively affects bilateral relations. At the same time, the realization of this vector in practical terms was continued as usual, within the framework of the same emphasis and directions as it was before 2008. This is confirmed, for instance, by Sweden's consent to construct "Nord Stream" gas pipeline through its Exclusive Economic Zone, stressing the importance of mutual trade and investment ${ }^{19}$, constant em-

15 O. Kempf, Friends in need. The Swedish Declaration of Solidarity, http://www.egeablog.net/index. php?post/2012/09/29/Friends-in-need.-The-Swedish-Declaration-of-Solidarity, access: 15 IX 2019.

16 Sweden and Finland Grant Permits to Nord Stream, https://www.nord-stream.com/press-info/ press-releases/sweden-and-finland-grant-permits-to-nord-stream-255/, access: 15 IX 2019.

17 L. Harding, Russia and Norway resolve Arctic border dispute, https://www.theguardian.com/ world/2010/sep/15/russia-norway-arctic-border-dispute, access: 18 IX 2019.

18 Unified Effort Expert Commission on Norwegian Security and Defence Policy, Norwegian Ministry of Defence, 2015, p. 71.

19 C. Bildt, Russia and the World - A View from Abroad, Government Offices of Sweden, Moscow, 21 May 2011. 
phasis on necessity to respect human rights and implement democratic development ${ }^{20}$, statements on support of integration of the RF into European and international institutions ${ }^{21}$. As for Norway, the corresponding confirmation is, for example, the development of cooperation in the High North, that was enhanced by delimitation of maritime borders in the Barents region, organization of joint border activities, as well as regular reminder of the necessity to respect human rights, implement democratic reforms and fight corruption. At the same time, the violation of international law by Russia, an increasingly reluctance to demonstrate progress in solving of internal state problems, has shown to Sweden and Norway the lack of prospects for stable, democratic, and reliable RF, at least during the rule of political elites headed by V. Putin.

\section{Aggression in Ukraine as a strong signal of Russian revisionism}

Fundamental changes in implementation of the Russian vector of foreign policy by Scandinavian countries began in 2014. Unfortunately for them, these changes were negative. After use of military force in Georgia and criticism of such actions by international community, the RF continued to aggravate the situation by act of aggression towards Ukraine. But, unlike Georgian situation, the annexation of Crimea and Russian actions in the East of Ukraine caused more significant effect among global community, and, in particular, among Scandinavian countries.

The Northern European states officially condemned the Russia's actions in Ukraine. For instance, one of the first reaction of the Norwegians was an official statement of the Minister for Foreign Affairs Borge Brende dated March 2, 2014, in which the Minister condemned the RF for military escalation in Crimea, noting that use of military forces in the territory of other state is a violation of international law ${ }^{22}$. Later, on March 14, 2019, this Minster stated that Norway did not recognize the results of "Crimean referendum" 23 , and already in March 18, B. Brende spoke out in condemnation of annexation of Crimea by Russia and expressed position that Norway would continue to consider the peninsula as the territory of Ukraine ${ }^{24}$.

But then, due to objective reasons caused by escalation of Russian aggression, the Northern European country resorted to more practical measures. These measures referred to imposition of sanctions against individuals responsible for actions that undermine or threaten the sovereignty and territorial integrity of Ukraine. It was

20 Speech by Carl Bildt at the OSCE Ministerial Council, Government Offices of Sweden, Vilnius, 06 December 2011.

21 C. Bildt, Statement of Government Policy in the Parliamentary Debate on Foreign Affairs, Ministry for Foreign Affairs Sweden, Stockholm, 2012, p. 8.

22 Norway condemns Russian military escalation in Crimea, https://www.regjeringen.no/en/aktuelt/ crimea/id752064/, access: 21 IX 2019.

23 Crimea referendum illegal and illegitimate, https://www.regjeringen.no/en/aktuelt/illegal_referendum/id753120/, access: 21 IX 2019.

24 Norway condemns Russia's annexation of Crimea, https://www.regjeringen.no/en/aktuelt/condemns_ russia/id753260/, access: 21 IX 2019. 
stated by the Norwegian government in the official press release regarding sanctions dated March 21, that such step had been caused by illegal activity of the $\mathrm{RF}^{25}$. After that, Norway along with European partners repeatedly prolonged and strengthened the economic sanctions against Russia due to continued escalation of the conflict in Ukraine $^{26}$. In response, the Russian party imposed an embargo on import from the range of states, in particular from Norway ${ }^{27}$. Such countermeasures demonstrated the unwillingness of the RF for de-escalation of the conflict and the reluctance to find constructive solutions for improvement of relations with Western states.

In addition to the economic sanctions Norway decided to suspend all planned military activities with Russia. It included the cancellation of joint naval trainings and postponement of visits of Russian representatives of military sector ${ }^{28}$.

It should be noted that general critical narrative towards Russia partially covered the vector concerning cooperation in the High North that is seen by Norway as the most important part of Norwegian-Russian relations. For instance, "The High North: visions and strategies" document of 2011 by the Ministry for Foreign Affairs of Norway described the relations with Russia as "one of greater confidence" 29 , and "The Arctic: major opportunities - major responsibilities" document of 2013 defined these relations as "good, positive and prospective" ${ }^{30}$. But, the similar document of 2014, along with emphasis on perspectives and necessity for cooperation in the region, raised the problem of violation of international law by Russia that could have negative impact on bilateral relations in general and, in particular, on cooperation in the High North ${ }^{31}$.

For its part, Sweden expressed more pointed and strict position on the Russia's actions in Ukraine. The criticism towards Russia was usually expressed by the Minister for Foreign Affairs C. Bildt. By the same politician, who had strongly criticized the RF for its aggression in Georgia and who was defined by Russian sources as one of the most anti-Russian politicians in Sweden ${ }^{32}$. It should be noted that C. Bildt, as an active promoter of "Eastern Partnership", criticized the Russia's actions towards Ukraine even

25 Measures against individuals whose actions threaten Ukraine's territorial integrity, https://www. regjeringen.no/en/aktuelt/Measures_against_individuals_whose_actions_threaten_Ukraines_territorial_integrity/id753686/, access: 21 IX 2019.

26 Norway tightens restrictive measures against Russia, https://www.regjeringen.no/en/aktuelt/Norway-tightens-restrictive-measures-against-Russia-/id2005821/, access: 21 IX 2019.

27 Foreign Minister Brende: 'Regrettable Russian import ban', https://www.regjeringen.no/en/aktuelt/ Foreign-Minister-Brende-Regrettable-Russian-import-ban/id765590/, access: 21 IX 2019.

28 Norway suspends all planned military activities with Russia, https://www.regjeringen.no/en/aktuelt/ Norway-suspends-all-planned-military-activities-with-Russia-/id753887/, access: 21 IX 2019.

29 "The High North: visions and strategies", Norwegian Ministry of Foreign Affairs, 2011, p. 9.

30 "The Arctic: major opportunities - major responsibilities", Norwegian Ministry of Foreign Affairs, 2013, p. 8.

31 "Norway's Arctic Policy", Norwegian Ministry of Foreign Affairs, 2014, p. 17.

32 Карл Бильдт: юбилейный портрет антироссийского шведского "ястреба", https://eadaily.com/ ru/news/2019/07/12/karl-bildt-yubileynyy-portret-antirossiyskogo-shvedskogo-yastreba, access: 24 IX 2019. 
before Ukrainian-Russian conflict. This criticism concerned the pressure from the RF on post-Soviet states in order to prevent deepening of their cooperation with European institutions and possible integration of the states into these institutions. For example, the Minister stated on that in annual foreign policy report dated February $2014^{33}$.

With the beginning of direct aggression of Russia towards Ukraine, the agenda of C. Bildt's speeches was mostly devoted to the RF. The majority of official statements and speeches of the Minister included condemnation of Russia's actions, their interpretation as threat to security and stability of Europe, and as extreme violation of international law ${ }^{34}$. For example, C. Bildt during one of the summits characterized Russia and its destabilizing influence in Europe in his speech titled "The Ukraine Crisis: What's Next for Europe?" in the following manner: "Instead of the more modern and open Russia that we had hoped would emerge - and that we still hope will emerge - we saw the development of Russia as an increasingly authoritarian petrostate. [...] Russia has emerged as a revisionist power violating and questioning the very foundations of the European order of peace and stability that we had started to build... 35 ".

Regarding practical measures for countering Russian revisionism, Sweden, as a member of the EU, along with European partners imposed the economic sanctions against actors responsible for aggression towards Ukraine on March 17, 2014 ${ }^{36}$. At the same time, it should be noted that Sweden was one of the EU states which stood for extending and toughening of sanctions in case of further Russia's aggression towards Ukraine. For instance, the Prime Minister Fredrik Reinfeldt in July 2014, called for broadening of sanctions by increasing the number of individuals and companies which engaged in Russian occupation and annexation of the parts of Ukrainian territory ${ }^{37}$.

Russian party, in its turn, claimed that it was also Sweden's fault, that such situation had happened. The Embassy of the Russian Federation in Sweden reproached the Scandinavian country for supporting the European integration of Ukraine, that, according to the Russian Embassy, became one of the reasons of such Russian aggressive activity ${ }^{38}$.

In October 2014, there were changes in the Government of Sweden. Therefore, the social-democrats have got the majority in the Riksdag. This, in turn, influenced

33 C. Bildt, Statement of Government Policy in the Parliamentary Debate on Foreign Affairs, Ministry for Foreign Affairs Sweden, Stockholm, 2014, p. 4.

34 C. Bildt, Information from the Government to the Riksdag concerning Ukraine and Russia, Government Offices of Sweden, 14 March 2014.

35 C. Bildt, The Ukraine Crisis: What's Next for Europe? Speech at the Summit on the Future of Europe, Government Offices of Sweden, 22 September 2014.

36 Sanktioner avseende Ryssland och Ukraina, https://www.regeringen.se/regeringens-politik/ utrikes--och-sakerhetspolitik/sanktioner/sanktioner-avseende-ryssland-och-ukraina/, access: 29 IX 2019.

37 Sweden pushes for tougher Russia sanctions, http://sverigesradio.se/sida/artikel.aspx?programid=2054\&artikel=5916241, access: 29 IX 2019.

38 P. O’Mahony, Russia blames Sweden for Ukraine crisis, https://www.thelocal.se/20150309/russiablames-sweden-for-ukraine-crisis, access: 25 III 2020. 
on the strictness of Sweden's position towards Russia, which became more moderate. For example, along with position regarding necessity to continue sanctions in case of absence of steps for de-escalation of conflict in Ukraine by Russian party, Swedes partially returned to the narrative of dialogue with Russia in order to support Russian civil society. In particular, the successor of C. Bildt, the Minister for Foreign Affairs Margot Wallstrom stated the necessity for dialogue. She, unlike her predecessor, who mostly criticized Russia's activity in an international context, started again to emphasize on problematic issues concerning human rights and democracy ${ }^{39}$. That is, on the issues that Sweden often highlighted within the process of cooperation with RF and implementation of foreign policy regarding this state before conflict in Georgia in 2008 and partially in the period between Georgian-Russian war and aggression towards Ukraine.

\section{Russian military activity in the region of Northern Europe}

Thus, we can state that annexation of Crimea, military aggression, and support for the separatists in the Eastern Ukraine became those factors of Russian revisionism which had negative impact on the Russian-Scandinavian cooperation and implementation of the Russian vector of Sweden's and Norway's foreign policy. But it should be noted that "Ukrainian case" was not the only reason of changes in the foreign policy of Scandinavian countries towards RF. The increasing of Russia's military activities in Northern Europe since 2014 became an additional factor for such changes. It is about growing activity of Russian military airplanes near Norway ${ }^{40}$, violation of Sweden's airspace ${ }^{41}$, provocations in the Baltic region ${ }^{42}$, as well as using of informational levers of impact in the region in order to influence public opinion ${ }^{43}$ and conduct illegal intelligence activity ${ }^{44}$.

In particular, the Minister of Defense Ine Eriksen Soreide expressed concern with regard to increasing of Russia's military activity near Norway in February 2015. According to her, the Norwegians noticed the increasing of activity, especially in air. As the Minister noted: "There is no going back to some sort of normality or some sort of back to normal business. Because that normality does not exist... We are faced with a different Russia. I want to warn against the fact that some people see this as something that is going to pass. The situation has changed. And it has changed profoundly."

39 F. Wesslau, View from Stockholm: The EU must stay the course, http://www.ecfr.eu/article/commentary_view_from_stockholm_the_eu_must_stay_the_course311443, access: 29 IX 2019.

$40 \mathrm{~J}$. Borger, Norway to restructure military in response to Russian 'aggression', https://www.theguardian. com/world/2015/feb/25/norway-to-restructure-military-in-response-to-russian-aggression, access: 03 X 2019.

${ }^{41}$ Russian jets spotted in Swedish airspace, https://www.thelocal.se/20140918/russian-jets-violate-swedish-airspace-report, access: 03 X 2019.

42 D. Axe, Su-27: This Plane Could Start a War Between Russia and NATO, https://nationalinterest. org/blog/the-buzz/su-27-plane-could-start-war-between-russia-nato-23202, access: 03 X 2019.

43 R. Standish, A New Cold Front in Russia's Information War, https://foreignpolicy.com/2018/10/03/ the-new-cold-front-in-russias-information-war-nato-norway/, access: 04 X 2019.

44 Russian spies pose as diplomats in Sweden, https://www.thelocal.se/20160317/russia-is-conducting-psychological-war-against-sweden, access: 04 X 2019. 
But I. Soreide also added: "That does not mean that we will not have a cooperation with Russia. Norway has had for decades we have [had] both a practical and pragmatic cooperation, and we still have a lot of $\mathrm{it}^{45}$." Stating this, the Minister has confirmed the continuing of implementation of "dual policy" principles by Norway towards Russia.

Russian party, in its turn, emphasized on the negative consequences in the context of increased NATO presence in the territory of Norway. Large-scale NATO military trainings in the territory of the Scandinavian country are interpreted by Russians as provocative step which makes Norway unpredictable and destabilizes situation in the North ${ }^{46}$. The Russian Federation actualizes the conflict factor with regard to the use of territory and resources of Svalbard. For instance, in 2015 then-Russian Deputy Prime Minister Dmitry Rogozin visited the archipelago despite of restrictions related to sanctions against Russia. Norwegian authorities, which found out about D. Rogozin's visit from the news, have regarded such act as provocation. But D. Rogozin and Russian authorities did not see any provocation in this visit. Moreover, Russian party accused Norway for restriction of Russian activity in the territory of archipelago, that is in contrary to the Svalbard Treaty. In this way, along with increased military activity in the North, Russia aims to strengthen its position in the region by using resource and territorial factor ${ }^{47}$.

The deteriorating security situation in the region caused by Russian actions was also noted by the Minister for Foreign Affairs of Sweden M. Wallstrom in the foreign policy report of 2015. The report included the following: "While the situation in our neighborhood makes it necessary to strengthen Sweden's defense capabilities, we are continuing to develop our military cooperation: with Finland, with our other Nordic neighbors, with the Baltic countries and with $\mathrm{NATO}^{48}$. According to this statement, Russian destabilizing military activity in the region influences the development of Sweden's defense policy, and, most importantly, it may influence the fundamental principles of the state's foreign policy, notably the approach to implementation of nonaligned status and neutrality. The deepening of relations with NATO and increasing of regional defense cooperation were mentioned in the National Security Strategy of 2017: "Sweden is participating actively in efforts to influence developments in our region. Swedish-Finnish cooperation on security and defense policy issues has been intensified. Both of our countries have developed our partnership with NATO, and this now includes a strategic dialogue on the Baltic Sea Security with the 28 NATO members.

45 M. Krever, Norway: 'We are faced with a different Russia', https://edition.cnn.com/2015/02/25/world/ amanpour-norway-ine-eriksen-soreide/index.html, access: 04 X 2019.

46 Russian buildup worries Norway before big NATO military exercise, https://www.reuters.com/article/us-norway-arctic-nato-russia/russian-buildup-worries-norway-before-big-nato-military-exercise-idUSKCN1MC123, access: 25 III 2020.

47 Trellevik A., Russia Has Always Challenged Norway on Svalbard. This Time, Parts of Its Criticism is Different, https://www.highnorthnews.com/en/russia-has-always-challenged-norway-svalbard-timeparts-its-criticism-different, access: 25 III 2020.

48 M. Wallstrom, Statement of Government Policy in the Parliamentary Debate on Foreign Affairs, Ministry for Foreign Affairs Sweden, Stockholm, 2015, p. 3. 
Cooperation with other Nordic countries and the Baltic states has been strengthened and is increasingly focused on regional security ${ }^{49}$.

For its part, Norway emphasized the importance of its NATO membership in the context of increase of Russian revisionism, in the White paper on foreign policy titled "Norway's Role and Interests in Multilateral Cooperation" dated June 14, 2019. But, at the same time, according to "dual policy" principles, the country also mentioned about close neighborly relations with the main aim of maintaining of dialogue and cooperation: "Our NATO membership is crucial to balancing Norway's asymmetric relationship with Russia - it contributes to predictability and underpins neighborly relations that are also characterized by dialogue and cooperation. ${ }^{50}$ "This document also includes criticism of Russian actions regarding interference in the internal and foreign affairs of other states ${ }^{51}$, and regarding failure to respect human rights ${ }^{52}$.

The similar criticism was expressed by Sweden. The above Sweden's National Security Strategy of 2017 notes that Russia is ready to use military force in order to gain political goals and also is ready to spend considerable resources for development of military capability while the economic development of other branches in the state is at a low level. Moreover, there are no positive changes in terms of respect for human rights in Russia, and on the contrary, the state becomes more authoritarian ${ }^{53}$.

However, it should be added, that despite of criticism from Sweden and Norway, and despite of practical measures in response to aggression towards Ukraine, other cases regarding violation of international law, increase of military activity in the Northern Europe, both Scandinavian countries still reserve some options for periodic lowering the tone of rhetoric and for concessions. In particular, it was demonstrated by Sweden's consent to construction of Nord Stream $2^{54}$, voting of Norwegian representatives in PACE for returning of the Russia's delegation ${ }^{55}$, restoration of the political dialogue between RF and Norway at ministerial level after 3-year suspense of contacts ${ }^{56}$.

49 "National Security Strategy", Government Offices of Sweden, Prime Minister's Office, 2017, p. 12.

50 "Norway's Role and Interests in Multilateral Cooperation", Meld. St. 27 (2018-2019) Report to the Storting (white paper), Norwegian Ministry of Foreign Affairs, 2019, p. 6.

51 Ibidem, p. 24.

52 Ibidem, p. 23.

53 "National Security Strategy", Government Offices of Sweden, Prime Minister's Office, 2017, p. 11.

54 Nord Stream 2 gets green light from Sweden, https://sverigesradio.se/sida/artikel.aspx?programid=2054\&artikel=6971876, access: 06 X 2019.

55 Challenge, on substantive grounds, of the still unratified credentials of the parliamentary delegation of the Russian Federation, http://assembly.coe.int/nw/xml/Votes/DB-VotesResults-EN.asp?VoteID=37990\&DocID=19023\&selSession=, access: 06 X 2019.

56 Solberg and Søreide to Putin's Grand Arctic Conference, https://www.highnorthnews.com/en/solbergand-soreide-putins-grand-arctic-conference, access: 06 X 2019. 


\section{Conclusions}

Thus, summarizing the features of Swedish and Norwegian foreign policy towards Russia, we can admit both common and different approaches of its implementation that arise from significant geopolitical circumstances. Such factors as NATO membership or non-aligned status, common border and range of territorial and resource issues of cooperation, and, of course, regional proximity had a significant impact on development of relations between Scandinavian states and Russia, as well as on implementation of Russian vector of Sweden's and Norway's foreign policy.

Describing this vector, we can conditionally divide it into several periods according to its implementation. The first one is the period of the 90's- early 2000's. The agenda of this period included the creation of treaty and legal framework for bilateral relations, as well as development of principles for cooperation with "new Russia". We can describe this period as time of hopes and expectations from Sweden and Norway for new quality of relations with successor of the former USSR. Besides, we can divide this period into two sub-periods, notably the period before presidency of V. Putin and the beginning of his presidency. The reason for such division is emphasis by Scandinavian countries on internal state problems in the RF in the early 2000's regarding failure to respect human rights, undemocratic development of the state that had negative impact on Russia's international reputation. The end of the first period was characterized by loss of hope by Northern European states for development of the RF as stable, reliable and democratic partner.

The next short-term period includes chronological framework of 2008 - the first half of 2009. It is characterized by deterioration in relations amid Russian aggression towards Georgia. We can observe the sharpening of position of Scandinavian countries towards Russia at that time. Georgian case demonstrated to whole world and particularly to Northern European states the emergence of Russian revisionism. But it was perceived by international community as exception to the rule or one-time temporary burst of aggression which will never happen again. Scandinavian countries maintained the similar attitude towards Russian aggression against Georgia. Thus that case had not a significant practical impact on Russian vector of their foreign policy.

We can observe the further improvement of relations that was demonstrated by Sweden's consent to construction of Nord Stream and delimitation of maritime borders between Norway and Russia. These events took place in the third period of implementation of Russian vector, notably in 2009-2013. The features of this period include the above-mentioned efficiency and effectiveness of relations that was demonstrated by solving the range of important economic and territorial issues that was accompanied by periodic criticism regarding undemocratic development and other problems of internal development in the RF.

The last period we determined so far is the period of 2014-2019. This is the time of deterioration in relations between Scandinavian countries and Russia. The reason for such deterioration was Russian aggression in Ukraine and increasing of Russian military activity in the Northern Europe. As a result, we could observe the imposition of 
sanctions against RF by Scandinavian countries, unequivocal condemnation of Russia's actions, as well as reconsideration of defense capabilities by Sweden and Norway.

In our opinion, further development of Russian vector of Scandinavian countries' foreign policy would depend on nature of the Russia's activity on the international stage. First of all, it is about the state of relations between the West and Russia in terms of which the Russian vector is mostly implemented. Of course, Russia's activity in the Northern Europe will be of great importance. Continuing of military provocations or increasing of military activity in the region will have negative impact on bilateral relations, and thus make it necessary for Scandinavian countries to increase defense expenditures. Besides, such course of events will potentially entail the increasing militarization of the High North by both Russia and NATO. In this scenario, Sweden will face the need to reconsider the relevance of its non-aligned status. For its part, Norway would face more difficulties regarding implementation of Russian vector of its foreign policy under the principles of "dual policy".

With regard to "Ukrainian issue", we suppose that it will not have a significant impact on Sweden's and Norway's policy towards Russia, provided the decrease of Russian military activity in the North and less confrontation between the West and Russia. Continuing of Russian aggression in Ukraine in that form which we observe nowadays (as of the end of 2019) would be the reason for further sanctions (provided the same position of EU and other Western partners) from Scandinavian countries and for periodic criticism of RF in the rhetoric of Sweden and Norway.

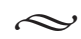

\begin{abstract}
The article presents the characteristics of the foreign policy of Sweden and Norway towards Russia. The chronological framework of the work covers the period from the collapse of the USSR and the beginning of the functioning of the Russian Federation as a separate actor in the international arena and up to the present day. The author analyzes the evolution of the policy of the Scandinavian countries towards Russia. The article sets out the main elements of the policy of these countries in relations with the Russian Federation. The researcher presents the main challenges that Sweden and Norway face today in the process of implementing this policy towards Russia.
\end{abstract}

Keywords: foreign policy, Russia, Sweden, Norway, dual policy, regional security

\title{
Cechy charakterystyczne polityki zagranicznej Szwecji i Norwegii wobec Rosji: główne problemy i wyzwania
}

Streszczenie: W artykule przedstawiono cechy charakterystyczne polityki zagranicznej Szwecji i Norwegii wobec Rosji. Ramy chronologiczne pracy obejmują okres od upadku ZSRR oraz początku funkcjonowania Federacji Rosyjskiej, jako oddzielnego aktora na arenie międzynarodowej, aż do czasów współczesnych. Autor analizuje ewolucję polityki państw skandynawskich wobec Rosji. W artykule wyznaczono główne akcenty polityki tych państw w stosunkach z Federacją Rosyjską. Badacz przedsta- 
Pobrane z czasopisma Wschód Europy http://journals.umcs.pl/we

Data: 26/04/2023 16:10:13

Features of Swedish and Norwegian foreign policy towards Russia: Main problems and challenges

wił główne wyzwania, wobec których stoją dziś Szwecja i Norwegia w procesie realizacji owej polityki wobec Rosji.

Słowa kluczowe: polityka zagraniczna, Rosja, Szwecja, Norwegia, polityka dualna, bezpieczeństwo regionalne

\section{Особенности внешней политики Швеции и Норвегии в отношении России: основные проблемы и вызовы}

Аннотация: Статья о российском векторе внешней политики Швеции и Норвегии. Хронологические рамки произведения охватывают период от распада СССР и начала становления Российской Федерации как отдельного актора на международной арене и до событий нашего времени. Автор анализирует трансформацию политики скандинавских государств в отношении России. В статье обозначены основные акценты данных стран в их отношениях с Российской Федерацией. Исследователь учитывает основные вызовы, с которыми сталкиваются Швеция и Норвегия в процессе реализации российского вектора своей внешней политики.

Ключевые слова: внешняя политика, Россия, Швеция, Норвегия, двойная политика, региональная безопасность

\section{Bibliography}

Axe D., Su-27: This Plane Could Start a War Between Russia and NATO, https://nationalinterest.org/ blog/the-buzz/su-27-plane-could-start-war-between-russia-nato-23202, 03 X 2019.

Bildt C., Information from the Government to the Riksdag concerning Ukraine and Russia, Government Offices of Sweden, 14 March 2014.

Bildt C., Russia and the World - A View from Abroad, Government Offices of Sweden, Moscow, 21 May 2011.

Bildt C., Russia's justification of its offensive deeply ominous, Ministry for Foreign Affairs Sweden, 2008

Bildt C., Statement of Government Policy in the Parliamentary Debate on Foreign Affairs, Ministry for Foreign Affairs Sweden, Stockholm, 2007, 13 p.

Bildt C., Statement of Government Policy in the Parliamentary Debate on Foreign Affairs, Ministry for Foreign Affairs Sweden, Stockholm, 2009, $12 \mathrm{p}$.

Bildt C., Statement of Government Policy in the Parliamentary Debate on Foreign Affairs, Ministry for Foreign Affairs Sweden, Stockholm, 2012, 14 p.

Bildt C., Statement of Government Policy in the Parliamentary Debate on Foreign Affairs, Ministry for Foreign Affairs Sweden, Stockholm, 2014, 12 p.

Bildt C., The Ukraine Crisis: What's Next for Europe? Speech at the Summit on the Future of Europe, Government Offices of Sweden, 22 September 2014.

Borger J., Norway to restructure military in response to Russian 'aggression', https://www.theguardian.com/world/2015/feb/25/norway-to-restructure-military-in-response-to-russian-aggression, access: $03 \times 2019$. 
Challenge, on substantive grounds, of the still unratified credentials of the parliamentary delegation of the Russian Federation, http://assembly.coe.int/nw/xml/Votes/DB-VotesResults-EN.asp?VoteID=37990\&DoclD=19023\&selSession=, access: 06 X 2019.

Country strategy for development cooperation with Russia 2002-2004, Ministry for Foreign Affairs, Department for Central and Eastern Europe, Stockholm, 2002, 26 p.

Country strategy for development cooperation with Russia 2005-2008, Ministry for Foreign Affairs, Department for Central and Eastern Europe, Stockholm, 2005, 26 p.

Crimea referendum illegal and illegitimate, https://www.regjeringen.no/en/aktuelt/illegal_referendum/ id753120/, access: 21 IX 2019.

Ekfeldt T., High North - low tension?, Lund 2017, 26 p.

Foreign Minister Brende: 'Regrettable Russian import ban', https://www.regjeringen.no/en/aktuelt/ Foreign-Minister-Brende-Regrettable-Russian-import-ban/id765590/, access: 21 IX 2019.

Frissel E., I. Oldberg, "Cool Neighbors”: Sweden's EU Presidency and Russia, IFRI, 2009, № 42, 20 p.

Gerhardsen W., How Norway promotes democracy in North-West Russia, Oslo 2007. 115 p.

Harding L., Russia and Norway resolve Arctic border dispute, https://www.theguardian.com/ world/2010/sep/15/russia-norway-arctic-border-dispute, access: 18 IX 2019.

Interests, Responsibilities and Opportunities The main features of Norwegian foreign policy, Report No.15 (2008-2009) to the Storting, $197 \mathrm{p}$.

Karł Bildt: jubilejnyj portriet antirossijskogoszwiedskogo "jastrieba", https://eadaily.com/ru/news/2019/07 /12/karl-bildt-yubileynyy-portret-antirossiyskogo-shvedskogo-yastreba, access: 24 IX 2019.

Kempf O., Friends in need. The Swedish Declaration of Solidarity, http://www.egeablog.net/index. php?post/2012/09/29/Friends-in-need.-The-Swedish-Declaration-of-Solidarity, access: 15 IX 2019.

M. Krever, Norway: "We are faced with a different Russia", https://edition.cnn.com/2015/02/25/world/ amanpour-norway-ine-eriksen-soreide/index.html, access: 04 X 2019.

M. Wallstrom, Statement of Government Policy in the Parliamentary Debate on Foreign Affairs, Ministry for Foreign Affairs Sweden, Stockholm, 2015, 8 p.

Measures against individuals whose actions threaten Ukraine's territorial integrity, https://www.regjeringen.no/en/aktuelt/Measures_against_individuals_whose_actions_threaten_Ukraines_territorial_integrity/id753686/, access: 21 IX 2019.

National Security Strategy, Government Offices of Sweden, Prime Minister's Office, 2017, 26 p.

Nord Stream 2 gets green light from Sweden, https://sverigesradio.se/sida/artikel.aspx?programi$d=2054 \&$ artikel=6971876, access: 06 X 2019.

Norway condemns Russia's annexation of Crimea, https://www.regjeringen.no/en/aktuelt/condemns_ russia/id753260/, access: 21 IX 2019.

Norway condemns Russian military escalation in Crimea, https://www.regjeringen.no/en/aktuelt/crimea/id752064/, access: 21 IX 2019.

Norway suspends all planned military activities with Russia, https://www.regjeringen.no/en/aktuelt/ Norway-suspends-all-planned-military-activities-with-Russia-/id753887/, access: 21 IX 2019.

Norway tightens restrictive measures against Russia, https://www.regjeringen.no/en/aktuelt/Norwaytightens-restrictive-measures-against-Russia-/id2005821/, access: 21 IX 2019.

Norway's Arctic Policy, Norwegian Ministry of Foreign Affairs, 2014, 23 p. 
Norway's Role and Interests in Multilateral Cooperation, Meld. St. 27 (2018-2019) Report to the Storting (white paper), Norwegian Ministry of Foreign Affairs, 2019, $80 \mathrm{p}$.

Oldberg I., Russia's "northern" foreign policy, Research Associate Swedish Institute of International Affairs, Stockholm, 2011, 8 p.

O'Mahony P., Russia blames Sweden for Ukraine crisis, https://www.thelocal.se/20150309/russia-blames-sweden-for-ukraine-crisis, access: 25 III 2020.

Russian buildup worries Norway before big NATO military exercise, https://www.reuters.com/article/ us-norway-arctic-nato-russia/russian-buildup-worries-norway-before-big-nato-military-exerciseidUSKCN1MC123, access: 25 III 2020.

Russian jets spotted in Swedish airspace, https://www.thelocal.se/20140918/russian-jets-violate-swedish-airspace-report, access: $03 \times 2019$.

Russian spies pose as diplomats in Sweden, https://www.thelocal.se/20160317/russia-is-conductingpsychological-war-against-sweden, access: 04 X 2019.

Sanktioner avseende Ryssland och Ukraina, https://www.regeringen.se/regeringens-politik/utrikes--och-sakerhetspolitik/sanktioner/sanktioner-avseende-ryssland-och-ukraina/, access: 29 IX 2019.

Solberg and Søreide to Putin's Grand Arctic Conference, https://www.highnorthnews.com/en/solbergand-soreide-putins-grand-arctic-conference, access: 06 X 2019.

Speech by Carl Bildt at the OSCE Ministerial Council, Government Offices of Sweden, Vilnius, 06 December 2011.

Standish R., A New Cold Front in Russia's Information War, https://foreignpolicy.com/2018/10/03/thenew-cold-front-in-russias-information-war-nato-norway/, access: 04 X 2019.

Sweden and Finland Grant Permits to Nord Stream, https://www.nord-stream.com/press-info/press-releases/sweden-and-finland-grant-permits-to-nord-stream-255/, access: 15 IX 2019.

Sweden helping Chechen 'bandits': Russia, https://www.thelocal.se/20100309/25432, access: 13 IX 2019.

Sweden invokes Hitler in condemning Russian assault, https://www.thelocal.se/20080809/13596, access: 13 IX 2019.

Sweden pushes for tougher Russia sanctions, http://sverigesradio.se/sida/artikel.aspx?programid=2054\&artikel=5916241, access: 29 IX 2019.

The Arctic: major opportunities - major responsibilities, Norwegian Ministry of Foreign Affairs, 2013, $12 \mathrm{p}$.

The High North: visions and strategies, Norwegian Ministry of Foreign Affairs, 2011, 44 p.

Trellevik A., Russia Has Always Challenged Norway on Svalbard. This Time, Parts of Its Criticism is Different, https://www.highnorthnews.com/en/russia-has-always-challenged-norway-svalbardtime-parts-its-criticism-different, access: 25 III 2020.

Unifiied Effort Expert Commission on Norwegian Security and Defence Policy, Norwegian Ministry of Defence, 2015, $105 \mathrm{p}$.

Wesslau F., View from Stockholm: The EU must stay the course, http://www.ecfr.eu/article/commentary_view_from_stockholm_the_eu_must_stay_the_course311443, access: 29 IX 2019. 